\title{
Retrospective evaluation of results of newborn hearing screening and importance of patient record system
}

\section{Yenidoğan işitme taramasi sonuçlarının retrospektif olarak değerlendirmesi ve hasta kayıt sisteminin önemliliği}

\author{
Adem Bora, Kasım Durmmuş, Emine Eliff Altuntaş
}

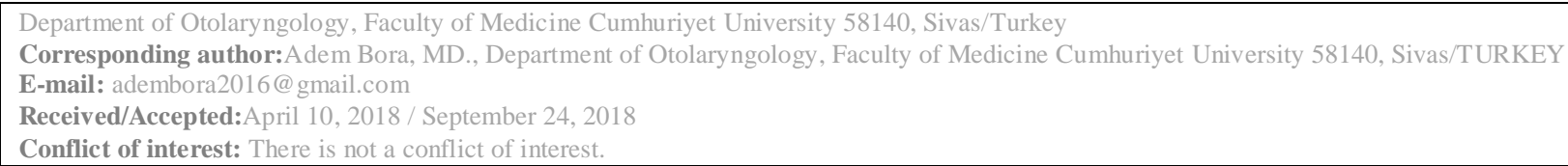

\section{SUMMARY}

Objective: The aim of the present study was to evaluate hearing screening results of 3490 newborns who underwent newborn hearing screening between 2015-2017 in Cumhuriyet University Faculty of Medicine Department of Otolaryngology, to asses deficiencies of our record system, and to share our retrospective results by comparing with the results in the literature.

Method: Hearing screening results of infants who were born in Cumhuriyet University between March 2015 and February 2017, were referred to neonatal intensive care or transferred from other out-of-town or inner city hospitals to our university was retrospectively evaluated in the present study.

Results: There was a statistically significant difference for the left ear TEOAE test results and gender ( $\mathrm{p}<0.05$, $\mathrm{p}=0.016, \mathrm{x}^{2}=5.78$ ). And also summarizes the distribution of $\mathrm{ABR}$ test results in terms of gender while failure rate was statistically significant in the right ear in terms of gender $\left(\mathrm{p}<0.05, \mathrm{p}=0.022, \mathrm{x}^{2}=1.33\right)$.

Conclusions: When results of the present study were evaluated, it was found that while they were similar to some results in the studies on this issue in the literature, they showed great differences than some of them. Our main goal was to evaluate insufficiencies in record systems of both our hospital and external centers while we were planning the present study. Our results revealed that these records were not paid enough attentions at external centers and our record system had some insufficiencies.

Keywords: Newborn, Hearing screening test, Data loss, record system 
Yöntem: Çalışmamızda 2015 - 2017 yılları arasında Cumhuriyet Üniversitesinde doğan, yenidoğan yoğun bakımına sevk edilen ya da şehir içi/dışı diğer hastanelerden üniversitemize gelen bebeklerin işitme taraması sonuçları retrospektif olarak değerlendirildi.

Bulgular: Sol kulak TEOAE test sonuçları ile cinsiyet arasında ki ilişki istatistiksel açıdan anlamlı idi $(\mathrm{p}<0.05, \mathrm{p}=$ $0.016, \mathrm{x} 2=5.78)$. Ayrıca sonuçlarının cinsiyete göre dağılımını özetlerken, başarısızlık oranı sağ kulağında cinsiyet açısından anlamlıdır $(\mathrm{p}<0.05, \mathrm{p}=0.022, \mathrm{x} 2=1.33)$. Sağ kulak da $\mathrm{ABR}$ testinde işitme kaybı tespit edilme oranları ile cinsiyet arasında ki ilişki istatistiksel açıdan anlamlı idi $\left(\mathrm{p}<0.05, \mathrm{p}=0.022, \mathrm{x}^{2}=1.33\right)$.

Sonuç: Sonuçlarımız değerlendirildiğinde literatürde yer alan bu konuda yapılmış olan çalışmalardaki kimi sonuçlar ile benzerlik gösterirken kiminden ise çok büyük farklılıklar göstermekteydi. Bu çalışmayı planlarken asıl amacımız hem kendi hastanemizin hem de dış merkezlerin kayıt sistemlerinde eksiklikleri değerlendirmekti. Sonuçlarımız dış merkezlerde bu kayıtların yeterince özenle tutulmadığını kendi kayıt sistemimizinde bazı eksiklikleri olduğunu göstermiştir.

Anahtar sözcükler: Yenidoğan İşitme Taraması, kayıp veri, kayıt sistemi

\section{INTRODUCTION}

Globally, 32 millions of children are estimated to have impaired hearing all around the world and a great majority of them are known to live in countries with low and middle income (1). Prevalence of newborn hearing loss has been stated to be 1-6/1000 infants in every live birth, $3 / 1000$ infants in average, this rate increases up to $10 / 1000$ in infants of risk group in neonatal intensive care units $(2,3)$.

Hearing loss may have a negative influence on language development, school performance, job opportunities in following periods of life, and quality of life psychosocially among individuals $(4,5)$. The World Health Organization suggests that children who have impaired hearing or are suspected to have such condition need to be tested within the first three months and to start treatment and rehabilitation in the 6 months of age $(6,7)$. Two methods are accepted for newborn hearing screenings. These are TEOAE (Transient Evoked Otoacoustic Emissions) and ABR (Auditory Brainstem Response) (8). In the present study, in accordance with newborn hearing screening protocol, TEOAE was used since it is technically simpler, short term, and reveals even very mild hearing loss $A B R$ was also used for evaluation of infants who were in risky group or failed TEOAE test.

Newborn hearing screening has been widely used all around the world in order to diagnose congenital hearing loss as early as possible. Early diagnosis as well as convenient treatment or interventions of rehabilitation are very important for children with impaired hearing in terms of maximizing both their social and mental development and their quality of life (9). Therefore, newborn hearing screening needs to be conducted delicately for all infants and to be recorded very well in order to prevent overlooking diagnoses of infants with hearing loss. Training has been provided in various centers regularly for this issue every year in Turkey. Because it is a reference center, our clinic has been working on this issue coordinately with Sivas Provincial Directorate of Health. On the other hand, since we have a concern about the fact that record system has not been paid sufficient attention, the aim of the present study was to evaluate hearing screening results of 3490 newborns who underwent newborn hearing screening between 2015-2017 in Cumhuriyet University Faculty of Medicine Department of Otolaryngology, to asses deficiencies of our record system, and to share our retrospective results by comparing with the results in the literature.

\section{MATERIAL AND METHODS}

Hearing screening results of infants who were born in Cumhuriyet University between March 2015 and February 2017, were referred to neonatal intensive care or transferred from other out-oftown or inner city hospitals to our university was retrospectively evaluated in the present study. Hearing screenings were performed by two audiometrists who were trained previously and certified for this issue. Families were informed before test protocol and their verbal and written consents were obtained. 
All of the infants underwent hearing screening after their otoscopic evaluation for fluid, debris, and cerumen in external auditory canal in order not to influence negatively test results in a period close to discharge following birth.

Hearing screenings were performed when infant was in lap of its mother or on a flat surface, in a quite environment, while being in natural sleep and full. TEOAE test was applied via Maico, ERO Scan Analyzer (GmbH Salzufer, 13/14, 10587, Berlin GE) device by choosing probes appropriate for the size of infant's external auditory canal. When the test was completed with this device; if there was a response, the result was viewed as "PASS" on the screen; "REFER" was viewed for ears showing no response. Receiving automatically the "PASS" result was accepted as the criteria of success for screening test in the present study.

Bilateral measurement was performed for infant in hearing screenings made by TEOAE test. Families of infants for whom unilateral or bilateral emission response was not obtained were informed and called 15 later for the test repetition. Otoscopic examination of infants who failed unilateral or bilateral TEOAE test among the infants coming for control was repeated for pathologies that may influence the result of fluid in middle ear or the result of test in external ear, and when there is a problem that may affect TEOAE response after the examination, necessary treatments and recommendations were made. Following the elimination of the presence of problem about external auditory canal and middle ear that may influence TEOAE response, infants were subject to the test again. ABR evaluation was performed with GN otometrics ICS chaptr EP 200 (Denmark) device by calling the infants, who failed TEOAE test in the first two controls, for the third time to perform ABR test. The result of ABR was given as passed or failed the test automatically. Screening results were provided to families in written. Screening findings of the infants were also recorded in the Hearing Screening Follow-up Form.

Various parameters, that were accessed by records of infants who were screened, such as gender, birth weight, type of birth, if they stayed in neonatal unit, gestational week, place of birth (our university or referral), TEOAE test results, ABR test results if performed were evaluated.

SPSS 22.0 program was utilized for evaluation of the obtained data. Differences between variables were evaluated by using the chi-square test. The data were stated in the number and percentage of cases. Level of significance was accepted as 0.05.

\section{RESULTS}

Within the 24-month evaluation period, a total of 3490 newborns were evaluated, $51.9 \%(\mathrm{n}=1812)$ were female, $47.1 \%(n=1643)$ were male, and gender information of $1 \% \quad(\mathrm{n}=35)$ could not accessed from the record system. 52.4\% of a total of 3455 cases whose gender information was accessed were female infants and $47.6 \%$ were male infants.

When the cases were evaluated in terms of the place of birth, it was found that while $28.7 \%$ $(\mathrm{n}=1000)$ were born at our university, $10.3 \%$ $(\mathrm{n}=358)$ were born at an external center. The rate of those whose birth place information could not be accessed from the data in our record system was $61.1 \%(\mathrm{n}=2132)$. While the number of infants whose birth place information was accessed via records was 1358 (38.9\%), $73.6 \%$ of them were born at our hospital.

When the results of TEOAE test were evaluated, it was found that while results of 2312 cases (66.2\%) were accessed, test results of 1178 (33.8\%) cases could not be accessed. When these results were evaluated statistically by considering the missing $33.8 \%$ of cases, it was revealed statistically that the number of cases failing TEOAE could varied between $14.9 \%$ and $48.7 \%$. While both ears of $14.9 \%(n=344)$ of the infants, whose TEOAE test results were accessed, failed the test and single ear of $10.0 \%(n=232)$ failed the test, $75.1 \% \quad(\mathrm{n}=1736)$ of the infants passed TEOAE test for both ears.

Table 1 summarizes distribution of TEOAE test results by gender immediately after birth. While failure rates of right ear were statistically insignificant by gender $(p>0.05, p=0.238$, $\mathrm{x}^{2}=1.33$ ), there was a statistically significant difference for the left ear $(\mathrm{p}<0.05, \mathrm{p}=0.016$, $\left.\mathrm{x}^{2}=5.78\right)$. 
Table 1 Results of the first TEOAE test in terms of gender

\begin{tabular}{|l|l|l|l|l|}
\hline \multicolumn{2}{|l|}{ TEOAE } & FEMALE \% (n) & MALE \% (n) & TOTAL \\
\hline \multirow{2}{*}{$\begin{array}{l}\text { Right } \\
\text { ear }\end{array}$} & REFER & $17.4(215)$ & $19.2(202)$ & $18.2(417)$ \\
\cline { 2 - 5 } & PASS & $82.6(1023)$ & $80.8(848)$ & $81.8(1871)$ \\
\hline \multirow{2}{*}{ Left ear } & REFER & $19.5(241)$ & $23.6(248)$ & $21.4(489)$ \\
\cline { 2 - 5 } & PASS & $80.5(996)$ & $76.4(802)$ & $78.6(1798)$ \\
\hline
\end{tabular}

ABR evaluation was applied for a total of 1111 cases in risk group of the study. While $6.4 \%$ $(n=71)$ of the infants, whose ABR test results were accessed, were failed in the test for both ears and $7.0 \%(n=78)$ for one ear. $86.6 \%(n=962)$ of the infants passed the screening test for both ears. As these results were evaluated for a total of 3490 cases, $31.8 \%$ were assessed. The number of the patients failing ABR would vary between $7 \%$ and $75.2 \%$ given that $68.2 \%$ of the cases were missing. Table 2 summarizes the distribution of ABR test results in terms of gender. While failure rate was statistically significant in the right ear in terms of gender $\left(p<0.05, p=0.022, x^{2}=1.33\right)$, the difference was statistically insignificant in the left ear $\left(p>0.05, p=0.191, x^{2}=1.70\right)$.

Table 2 Results of ABR test in terms of gender

\begin{tabular}{|l|l|l|l|l|}
\hline \multicolumn{2}{|l|}{ TEOAE } & FEMALE \% (n) & MALE \% (n) & TOTAL \\
\hline \multirow{2}{*}{$\begin{array}{l}\text { Right } \\
\text { ear }\end{array}$} & REFER & $12.2(66)$ & $8.0(45)$ & $10.0(111)$ \\
\cline { 2 - 5 } & PASS & $87.8(477)$ & $92.0(517)$ & $90.0(994)$ \\
\hline \multirow{2}{*}{ Left ear } & REFER & $10.9(59)$ & $8.5(48)$ & $9.7(107)$ \\
\cline { 2 - 5 } & PASS & $89.1(543)$ & $91.5(562)$ & $90.3(1105)$ \\
\hline
\end{tabular}

In the study, gestational information of 1002 newborns was reached, the mean gestational week was $37.15 \pm 2.82$ (min-max: 23-42). 96.7\% $(n=969)$ of these infants, such data of whom were accessed, were born at our university.

While birth weight data of 1028 out of the infants evaluated in the study were accessed, mean birth weight was $2933.46 \pm 760.68$ (min-max: 217.05220.0). $96.3 \%(\mathrm{n}=990)$ of the infants whose birth weight information was accessed were born at our university. When birth weights of the infants were grouped as below and above 1500 grams; it was determined that while $6.0 \%(\mathrm{n}=62)$ had a birth weight less than 1500 grams, $94.0 \%(n=966)$ had a birth weight of 1501 grams and higher. As the infants whose birth weight, TEOAE and ABR test results could be accessed were evaluated, the obtained test results were summarized in Tables 3 and 4. While the correlation between birth weight and the rates of failing TEOAE test was statistically insignificant in the right ear ( $p>0.05$, $\mathrm{p}=0.085, \mathrm{x}^{2}=2.96$ ), the difference was found to be statistically significant in the left ear $(\mathrm{p}<0.05$, $\mathrm{p}=0.001, \mathrm{x}^{2}=12.40$ ). The correlation between birth weight and the rates of $A B R$ test failure was statistically insignificant in both right and left ears $\left(\mathrm{p}>0.05, \mathrm{p}=0.770, \mathrm{x}^{2}=0.08\right.$ and $\mathrm{p}>0.05, \mathrm{p}=0.869$, $\mathrm{x}^{2}=0.02$; respectively). 
Table 3 Results of the first TEOAE test in terms of the birth weight of newborn

\begin{tabular}{|l|l|l|l|l|}
\hline \multicolumn{2}{|l|}{ TEOAE } & $\begin{array}{l}\text { <1500 gr } \\
\text { \% (n) }\end{array}$ & $\mathbf{1 5 0 1}$ gr & TOTAL \\
\hline \multirow{2}{*}{$\begin{array}{l}\text { Right } \\
\text { ear }\end{array}$} & REFER & $28.1(9)$ & $16.5(128)$ & $16.9(137)$ \\
\cline { 2 - 5 } & PASS & $71.9(23)$ & $83.5(649)$ & $83.1(672)$ \\
\hline \multirow{2}{*}{ Left ear } & REFER & $43.8(14)$ & $18.6(144)$ & $19.6(158)$ \\
\cline { 2 - 6 } & PASS & $56.3(18)$ & $81.4(632)$ & $80.4(650)$ \\
\hline
\end{tabular}

Table 4 Results of ABR test in terms of birth weight of newborn

\begin{tabular}{|l|l|l|l|l|}
\hline \multicolumn{2}{|l|}{ ABR } & $\begin{array}{l}\text { <1500 gr } \\
\text { \% (n) }\end{array}$ & $\mathbf{1 5 0 1}$ gr & TOTAL \\
\hline \multirow{2}{*}{$\begin{array}{l}\text { Right } \\
\text { ear }\end{array}$} & REFER & $8.7(2)$ & $7.0(10)$ & \\
\cline { 2 - 6 } & PASS & $91.3(21)$ & $93.0(133)$ & $7.2(12)$ \\
\hline \multirow{2}{*}{ Left ear } & REFER & $8.7(2)$ & $9.8(14)$ & $92.8(154)$ \\
\cline { 2 - 6 } & PASS & $91.3(21)$ & $90.2(129)$ & $9.6(16)$ \\
\hline
\end{tabular}

Among the infants whose TEOAE test results were accessed and birth weight was less than 1500 grams, it was found that while both ears failed in $22.9 \%(n=8)$ and one ear failed in $20.0 \%(n=7)$, $57.1 \%(\mathrm{n}=20)$ passed in both ears. Among the infants having a birth weight more than 1500 grams, $77.5 \%(\mathrm{n}=599)$ passed the test for both ears; whereas both ears failed the test in $12.5 \%$ $(\mathrm{n}=97)$ and one ear in $10.0 \% \quad(\mathrm{n}=77)$. When considering the missing $76.8 \%$ of the cases having a birth weight less than 1500 grams, it was statistically observed that the number of the cases failing TEOAE could vary between $12.9 \%$ and $56.4 \%$, and when considering the missing $20.0 \%$ of the cases having a birth weight more than 1500 grams, the number of cases failing TEOAE could vary between $10 \%$ and $30 \%$.

Among infants whose ABR test results were accessed and birth weight was less than 1500 grams, both ears failed the test in $8.3 \%(\mathrm{n}=2)$, one ear failed the test in $0 \%(\mathrm{n}=0)$, and $91.7 \%(\mathrm{n}=22)$ passed for both ears; on the other hand, among the infants having a birth weight more than 1500 grams, both ears failed the test in $4.9 \%(\mathrm{n}=7)$, one ear failed the test in $7.0 \%(\mathrm{n}=10)$, and $88.0 \%$ $(n=125)$ passed the test for both ears. While considering the missing $61.3 \%$ of the cases having a birth weight less than 1500 grams, it was statistically observed that the number of the cases failing ABR could vary between $3.2 \%$ and $64.5 \%$; on the other hand, when considering the missing $85.3 \%$ of those having a birth weight more than 1500 grams, it was statistically observed that the number of the cases failing ABR could vary between $0.7 \%$ and $86.0 \%$.

The information of $74.6 \%(n=2605)$ of the cases concerning whether or not they were followed up in intensive care unit was not accessed from our record system; on the other hand, such information of the remaining $25.4 \%(\mathrm{n}=885)$ cases were reached. $8.5 \%(n=295)$ of these cases were followed up in intensive care unit after the birth. 
$30.6 \%(n=267)$ of 295 cases who were followed up in intensive care unit were the infants born at our university. While results of a total of 189 cases $(64.1 \%)$ could be accessed in terms of TEOAE test results of infants hospitalized in intensive care unit, test results of $106(35.9 \%)$ could not be reached. While both ears failed the test in $11.1 \%(n=21)$ of infants whose TEOAE test result was accessed and one ear failed the test in $13.8 \% \quad(n=26), 75.1 \% \quad(n=142)$ of infants passed the first screening test for both ears. When considering the missing part, statistical results showed that the number of cases being followed up in intensive care unit and failing TEOAE could vary between $13.8 \%$ and $49.7 \%$. The correlation between follow up in intensive care unit and the rate of TEOAE test failure was statistically insignificant for both right and left ears $(\mathrm{p}>0.05$, $\mathrm{p}=0.577, \mathrm{x}^{2}=0.31$ and $\mathrm{p}>0.05, \mathrm{p}=0.622, \mathrm{x}^{2}=0.24$; respectively). Table 5 summarizes the distribution of TEOAE test results immediately after birth in terms of the state of following up the infants in intensive care unit.

Table 5 Results of the first TEOAE test in terms of following up newborn in intensive care unit

\begin{tabular}{|l|l|l|l|l|}
\hline \multicolumn{2}{|l|}{ TEOAE } & $\begin{array}{l}\text { Followed up in } \\
\text { intensive care unit } \\
\%(n)\end{array}$ & $\begin{array}{l}\text { Not followed up in } \\
\text { intensive care unit } \\
\%(\mathbf{n})\end{array}$ & TOTAL \\
\hline $\begin{array}{l}\text { Right } \\
\text { ear }\end{array}$ & REFER & $16.9(32)$ & $15.2(76)$ & $15.7(108)$ \\
\cline { 2 - 6 } & PASS & $83.1(157)$ & $84.8(424)$ & $84.3(581)$ \\
\hline \multirow{2}{*}{ Left ear } & REFER & $19.0(36)$ & $17.4(87)$ & $17.9(123)$ \\
\cline { 2 - 6 } & PASS & $81.0(153)$ & $82.6(412)$ & $82.1(565)$ \\
\hline
\end{tabular}

As ABR test results of the infants hospitalized in intensive care unit were evaluated, it was determined that while results of a total of 90 cases $(30.5 \%)$ were accessed, test results of 205 cases $(69.5 \%)$ could not be reached. While $6.7 \%(n=6)$ of the infants whose ABR test result were reached failed the test for both ears and $2.2 \%(\mathrm{n}=2)$ for one ear, $91.1 \%(\mathrm{n}=82)$ of infants passed the first screening test for both ears. When considering the missing part, the number of patients failing ABR was statistically seen to vary between $6.7 \%$ and $76.2 \%$. Table 6 summarizes the distribution of ABR test results immediately after birth in terms of the state of following up the infants in intensive care unit. The correlation between the state of being followed up in intensive care unit and the rates of ABR test failure was statistically insignificant for both right and left ears ( $p>0.05$, $\mathrm{p}=0.812, \mathrm{x}^{2}=0.05$ and $\mathrm{p}>0.05, \mathrm{p}=0.784, \mathrm{x}^{2}=0.07$; respectively). 
Table 6 Results of ABR test in terms of following up newborn in intensive care unit

\begin{tabular}{|l|l|l|l|l|}
\hline \multicolumn{2}{|l|}{ TEOAE } & $\begin{array}{l}\text { Followed up in } \\
\text { intensive care unit } \\
\%(n)\end{array}$ & $\begin{array}{l}\text { Not followed up in } \\
\text { intensive care unit } \\
\%(\mathbf{n})\end{array}$ & TOTAL \\
\hline \multirow{2}{*}{$\begin{array}{l}\text { Right } \\
\text { ear }\end{array}$} & REFER & $6.7(6)$ & $7.6(6)$ & $7.1(12)$ \\
\cline { 2 - 6 } & $P A S S$ & $93.3(84)$ & $92.4(73)$ & $92.9(157)$ \\
\hline \multirow{2}{*}{ Left ear } & REFER & $8.9(8)$ & $10.1(8)$ & $9.5(16)$ \\
\cline { 2 - 6 } & $P A S S$ & $91.1(82)$ & $89.9(71)$ & $90.5(153)$ \\
\hline
\end{tabular}

\section{DISCUSSION}

The present study retrospectively analyzed the data of 3490 infants obtained from national newborn hearing screening system and current newborn records of our university by involving the last 24-month period. Although the number of newborns with complete information was sufficient for taking sample (confidence interval of $95 \%$, error of $5 \%$ ) and making analysis, fundamentals to identify sample were needed to be ignored in this situation. This is because, taking sample among the available convenient number of patients may lead to bias for the whole population, therefore accuracy of the results becomes open to discussion. Due to such loss of data, we prefer not to indicate definite judgements for comparison of TEOAE and ABR test results with parameters such as birth weight, the state of being followed up in intensive care unit, and gender.

As it is all around the world, the primary objective of a successful newborn hearing screening in Turkey is to diagnose hearing loss before infant is three months old and to start treatments when it is 6 months old (4). Our clinic follows this program very studiously. The test is absolutely performed before discharge of infants and healthcare professionals working at both gynecology and neonatal departments are informed regularly to ensure this process. As much as we observed when we were bringing our results together, records related to risk conditions of infants undergoing screening in our clinic were in reliable limits to evaluate statistically but numerous data of infants coming from city center and external centers in the districts were missing. This both led us to make plans about the necessity to provide regular information for other institutions and indicated the necessity of using the follow up form for evaluations to record exactly infants born at external centers. No doubt, this is an important point that all institutions need to pay attention. We wanted to point out in the present study that it would be how important for institutions to review retrospectively these records sometimes to see insufficiencies of current process and for clinics to bring themselves into better positions.

Another point we would like to point out with this study is the importance of genetic consultancy as much as early diagnosis and treatment or amplification of hearing loss. Consanguineous marriages are still very frequent in regions that are developing like Sivas in Turkey and are underdeveloped economically compared to overall country. Relationship by affinity should be examined for families of infants failing hearing screening in such regions and families must definitely be informed about the importance of this issue.

Hearing loss is an important state of disability that influences whole life of individual from physical, social, and economic aspects. Therefore, it is also very important to decline the economic burden for our country to reveal preventable reasons early. Regular records of data belonging to hearing loss will allow to review regularly the results obtained in stages of diagnosis, treatment and amplification and to make better plans to decrease the associated financial burden. 


\section{CONCLUSION}

When results of the present study were evaluated, it was found that while they were similar to some results in the studies on this issue in the literature, they showed great differences than some of them. Our main goal was to evaluate insufficiencies in record systems of both our hospital and external centers while we were planning the present study. Our results revealed that these records were not paid enough attentions at external centers and our record system had some insufficiencies. In conclusion, these results allowed us to point out necessity and importance of forming a practical recording system by also updating our record system as well as entering data of national hearing screening database of infants in our clinic.

\section{REFERENCES}

1. Bright T, Mulwafu W, Thindwa R, Zuurmond M, Polack S. Reasons for low uptake of referrals to ear and hearing services for children in Malawi. PLoS One. 2017; 12(12): e0188703.

2. Grandori F, Lutman ME. European Consensus Statement on Neonatal Hearing Screening Finalized at the European Consensus Development Conference on Neonatal Hearing Screening. 15-16 May 1998, Milan Acta Paediatrica, 1999; 88: 107-107.

3. Poonual W, Navacharoen N, Kangsanarak J, Namwongprom S, Saokaew S. Hearing loss screening tool (COBRA score) for newborns in primary care setting. Korean $\mathbf{J}$ Pediatr. 2017; 60(11): 353-358.

4. World Health Organization. Childhood Hearing Loss 2015 [cited 2017 29/01/2017]. Available from: http://www.who.int/pbd/deafness/worldhearing day/WHD2016_Brochure_EN_2.pdf.

5. Garramiola-Bilbao I, Rodriguez-Alvarez A. Linking hearing impairment, employment and education. Public health. 2016; 141: 130-5.

6. Genç AG, Başar F, Kayıkçı ME, ve ark. Hacettepe Üniversitesi yenidoğan işitme taraması bulguları. Çocuk Sağlığı ve Hastalıkları Dergisi 2005;48:119-24.

7. Khaimook W, Chayarpham S, Dissaneevate $\mathrm{S}$. The high-risk neonatal hearing screening program in Songklanagarind Hospital. J Med Assoc Thai. 2008;91:1038-1042.

8. American Academy of Pediatrics, Joint Committee on Infant Hearing. Year 2007 position statement: Principles and guidelines for early hearing detection and intervention programs. Pediatrics. 2007;120:898-921.

9. Olusanya BO, Neumann KJ, Saunders JE. The global burden of disabling hearing impairment: a call to action. Bulletin of the World Health Organization. 2014; 92(5): 367-73. 